\title{
Measuring Energy Poverty and Its Impact on Economic Growth in Pakistan
}

\author{
Shafqut Ullah ${ }^{1}$, Muhammad Khan ${ }^{2}$ (D) and Seong-Min Yoon ${ }^{3, *(D)}$ \\ 1 Department of Economics, National University of Modern Languages (NUML), Islamabad 44000, Pakistan; \\ hshafqut@numl.edu.pk \\ 2 Department of Social Sciences, Islamabad (Campus), IQRA University, Islamabad 44000, Pakistan; \\ khann.muhammad@gmail.com \\ 3 Department of Economics, Pusan Natinal University, Busan 46241, Korea \\ * Correspondence: smyoon@pusan.ac.kr
}

Citation: Ullah, S.; Khan, M.; Yoon, S.-M. Measuring Energy Poverty and Its Impact on Economic Growth in Pakistan. Sustainability 2021, 13, 10969. https://doi.org/10.3390/ su131910969

Academic Editors: Sahbi Farhani and Khaled Guesmi

Received: 14 August 2021

Accepted: 26 September 2021

Published: 2 October 2021

Publisher's Note: MDPI stays neutral with regard to jurisdictional claims in published maps and institutional affiliations.

Copyright: (c) 2021 by the authors. Licensee MDPI, Basel, Switzerland. This article is an open access article distributed under the terms and conditions of the Creative Commons Attribution (CC BY) license (https:// creativecommons.org/licenses/by/ $4.0 /)$.

\begin{abstract}
During the last two decades, energy poverty has captured the growing attention of researchers and policymakers due to its strong association with economic poverty and poor economic performance. This study uses a broad set of macro level indicators and makes the first attempt to measure energy poverty and its impact on economic growth of Pakistan over the period of 1990 to 2017. Our energy poverty indicator considers four main dimensions of energy poverty, namely, energy services, clean energy, energy governance and energy affordability. A composite value of the energy poverty index shows that although the overall energy poverty has reduced in Pakistan during the selected sample period, the country shows an increasing dependence on polluted energy supply to meet its growing energy demand. In the second stage of investigation, the study tests the neoclassical growth theory where we incorporate energy poverty along with human capital as a source of economic growth. The main findings show a stable short-run cointegration between energy poverty and economic growth. These strong negative linkages between energy poverty and economic growth for the sample economy complement the previous literature on the subject.
\end{abstract}

Keywords: energy poverty; economic growth; energy governance; multidimensional poverty

\section{Introduction}

According to Prof. Nurkse, a country is poor due to its poor performance on the demand and supply sides of its economy [1]. Further, this poor performance pushes the society into a vicious cycle of poverty. Limited or low access to economic opportunities is a sign of economic poverty and vice versa. On the same token, energy poverty is a situation where a household does not meet the materially and socially established level of energy [2]. Likewise, at the aggregate level, the unavailability of modern and cheap sources of energy are considered a hurdle for efficient productivity, which strengthens the vicious cycle of poverty [3]. In the present era, the energy sector is facing two global issues, namely, energy security and global warming. Both these issues are directly and indirectly linked with energy poverty which further causes economic poverty [4]. Therefore, an energy poor nation is unlikely to fight with the other social and economic evils due to its inability to use modern and affordable energy for economic activities [5]. Poor nations, despite spending a large portion of their limited income on expensive and dirty energy, get (and provide) sub-optimal energy services. In this sense, the problem of poverty remains closely intertwined with a lack of cleaner and affordable energy services.

Despite the key importance of the subject, precise measurement of energy poverty turns out to be an unsolved puzzle in the empirical literature. The main problem is that energy poverty cannot be measured with a single proxy variable since the resulting indicator would only partially represent this menace. Indeed, as argued by Atkinson and Bourguignon [6], measurement of energy poverty is a tough job, and the factors such 
as economic, infrastructural and social development, and the ones related to the overall environmental quality, can easily influence this indicator [7]. Therefore, designing an energy poverty index that covers all these aspects becomes an important tool to address the modern global agenda. A comprehensive and multidimensional energy poverty index can also be used to bring together heterogeneous aspects of energy poverty and to see their impact on economic poverty. All this can certainly help us in formulating polices in order to break the vicious cycles of poverty.

The modern global energy agenda simultaneously focuses on the alleviation of economic and energy poverties. Every country is trying to provide universal access to clean and affordable energy by 2030 according to Sustainable Development Goals (SDGs 2015; for more details, visit https:/ / www.undp.org/sustainable-development-goals, accessed on 5 July 2021). To bring modern solutions to these issues, the question related to the precise measurement of energy poverty remains important for the policymakers and researchers working in this field [4,8].

Regarding the sample economy of this paper, energy crisis (or energy poverty) is the largest drain of the economy of Pakistan that hurts the GDP by two to four percent annually [9]. The availability of energy is quite low in the country. For instance, in 2017, per capita energy consumption was hardly near $500 \mathrm{~kg}$ of ton of oil equivalent (TOE), as compared to developed countries where per capita energy consumption is on average $6000 \mathrm{~kg}$ of TOE per capita. The Pakistan economy has experienced various issues that determine the status of its energy poverty over time. These include fiscal issues (i.e., circular debt, subsidies, and import bill), energy governance related issues (i.e., transmission and distribution losses, effective energy pricing and institutional backwardness or lack of transparency), and environmental aspects (i.e., a heavy reliance on dirty energy sources despite the vast potential of green energy in the country). It is also worth mentioning that our sample economy is going through the transitional phases of the growth path, where energy intensity increases with the process of economic development. Similarly, the factors such as rapid population growth and expansion of industrial and transport sectors are also causing more energy demand over time, widening the energy gap in Pakistan [10].

Exact quantification of the energy poverty, nonetheless, remains a challenging task for both energy economists and policymakers. In the literature, there are mainly three approaches to quantify this concept. The first one is "The Ten Percent Rule" (TTPR) by $[11,12]$, the second method relies upon drawing a threshold level of energy use with some engineering models [13-15], and the third technique constructs a comprehensive index for energy poverty $[16,17]$.

The present study follows the last approach to accomplish its first objective and hence relies upon an index to calculate the energy poverty of Pakistan. To the best of our knowledge, this study makes a seminal attempt to measure the energy poverty by utilizing time series data of the Pakistan economy. The second objective is to empirically investigate the dynamic impact of energy poverty on the economic growth of Pakistan.

The rest of the study is structured as follows. Section 2 contains definition, classification, related literature, and methodology about the measurement of energy poverty. Section 3 presents the methodology for our econometric analysis. Results and discussion are provided in Section 4 . Section 5 presents our conclusions and some important suggestions for policy purposes.

\section{Energy Poverty: Some Measurement Issues}

Measurement of energy poverty remains an unresolved issue in empirical energy-developm ent literature. To this end, the seminal contribution came from Boardman [11] who gives the concept of (fuel) energy poverty and tried to measure it for the UK economy after the oil price shocks of 1970s. However, the study takes only two aspects of energy poverty, namely, energy availability and energy affordability. In the subsequent literature, a bulk of studies tried to measure energy poverty using various indicators and sample economies $[3,7,18,19]$. These studies can mainly be divided into three categories. In the first category, energy poverty is simply 
measured by the share of income or expenditure of household going to energy consumption. If a household is unable to spend a threshold level of income on energy, then it is considered to be energy poor $[15,20]$. Schuessler [12] called this "The Ten Percent Rule". Nevertheless, this approach contains some serious measurement issues since it is widely held in the literature that households mostly over-report their income shares on energy consumption and under-report their exact income. The second approach draws a threshold level of energy via engineering (technology) based estimations [21]. This method of obtaining the threshold level of energy poverty is highly technical and it has been revised overtime. One important drawback of this method is that it focuses only on absolute energy poverty and thus does not incorporate the relative energy poverty. An appropriate energy poverty index should be a combination of both socio-economic and technological factors rather than income share and conventional engineering considerations. The third approach is concordant with the construction of a multidimensional or comprehensive index to analyze energy poverty $[16,22]$. This approach is comprehensive since it incorporates several socio-economic and technological aspects of energy poverty. This method also presents the evolution of energy situations over time.

The present study follows the last approach and constructs a multidimensional index for energy poverty in Pakistan using time series data from 1990 to 2017. Our selection of the starting sample year is based on the availability of data for several indicators of energy poverty. The reliability and authenticity of the data is the foundational stone for any empirical investigation. This study uses various authentic sources of secondary data for the construction of an energy poverty index in the case of Pakistan. Table 1 reports the data sources of all the indicators of the energy poverty index. Further, the index is categorized into four dimensions: energy services availability, clean energy, energy governance and energy affordability. These four dimensions are then based on seventeen indicators. The following sections elaborate the rationale behind using each indicator of the selected categories of the index.

Table 1. Multidimensional energy poverty index.

\begin{tabular}{|c|c|c|c|c|}
\hline & Dimensions & Indicators & Hypothesis & Data Source \\
\hline \multirow{17}{*}{ 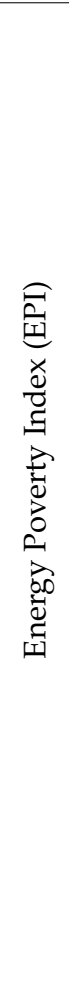 } & \multirow{5}{*}{$\begin{array}{l}\text { Energy } \\
\text { Services }\end{array}$} & Access to electricity, rural (\% of rural population) & + & WDI * \\
\hline & & Domestic crude oil production (TOE) & + & IEA ** \\
\hline & & Total energy supply by all sources in KTOE & + & IEA \\
\hline & & Access to electricity ( $\%$ of urban population) & + & WDI \\
\hline & & Energy use (kg of oil equivalent) & + & WDI \\
\hline & \multirow{6}{*}{$\begin{array}{l}\text { Clean } \\
\text { Energy }\end{array}$} & Alternative and nuclear energy ( $\%$ of total energy use) & + & PEB *** \\
\hline & & $\mathrm{CO}_{2}$ emissions (metric tons per capita) & - & WDI \\
\hline & & $\begin{array}{l}\text { Access to clean fuels and technologies for cooking ( } \% \\
\text { of population) }\end{array}$ & + & WDI \\
\hline & & Share of renewable energy (hydro production) & + & IEA \\
\hline & & Share of non-renewable (coal consumption KTOE) & - & IEA \\
\hline & & Biofuels and waste KTOE & - & IEA \\
\hline & \multirow{3}{*}{ Energy Governance } & $\begin{array}{l}\text { Transmission and distribution losses (electricity } \\
\text { billion kwh) }\end{array}$ & - & PEB \\
\hline & & Generation billion KW & + & IEA \\
\hline & & Energy imports, net (\% of energy use) & - & WDI \\
\hline & \multirow{3}{*}{ Energy Affordability } & Number of consumers of gas & + & PEB \\
\hline & & Registered four wheels out of 1000 people & + & PBS **** \\
\hline & & Registered two wheels for 1000 people & + & PBS \\
\hline
\end{tabular}

Notes: * World Development Indicators of World Bank, ${ }^{* *}$ International Energy Agency, ${ }^{* * *}$ Pakistan Energy Year Book (various editions), **** Pakistan Bureau of Statistics. 


\subsection{Energy Services Availability}

The first dimension of the energy poverty index is energy services availability (see Table 1). Availability of energy at affordable prices is a real challenge for developing countries. At the same time, it is considered an important source for sustainable development in developed nations [23]. Developing countries not only have to meet their growing energy needs but are also required to enhance their renewable energy capacity to meet the Sustainable Development Goals (SDGs 2015) of UNDP [3]. Taking the case of the Pakistan economy, Shahbaz [24] shows that the unavailability of energy has held back the annual GDP growth rate of the country by about two percent during the period 1991 to 2013. Okun's Law states that the unavailability of energy services causes unemployment [25]. Further, the existing literature also shows a strong relationship between energy poverty and provision of energy services for Pakistan [13,14]. Availability of energy services is also used as a proxy variable to measure energy poverty in Europe [26]. The International Energy Agency (IEA) described energy poverty as "a lack of access to modern energy services ..." . (see http:/ / www.iea.org/topics/energypoverty/, accessed on 5 July 2021). Wang et al. [16] also linked energy poverty with the availability of quality energy services. In this study, following the suggestions by international organizations and previous empirical studies, energy services availability is used as the first dimension of our energy poverty index.

Five other indicators are also used in the construction of this dimension as representatives of energy services availability by assigning equal weights. Four indicators are taken from supply side and one composite indicator, total energy use, from the demand side of energy services. Our first indicator covers energy services dimension and is based on rural population's access to electricity [16]. In Pakistan, distribution of electricity is totally managed by the public sector. According to WDI estimates, $63.56 \%$ of the country's population is still living in rural areas (for more details, visit https:/ / data.worldbank.org/indicator/SP.RUR.TOTL.ZS?locations=PK, accessed on 5 July 2021). However, in 2017 , around $97 \%$ of the rural population had access to electricity, which is a substantial improvement over 1990 when only $45 \%$ of the rural population had electricity. Our remaining three supply side variables include domestic crude oil production, total energy supply by all potential sources and access to electricity as percentage of urban population. A higher rate of domestic oil production lowers the dependence on imported energy and hence reduces energy poverty.

\subsection{Clean Energy}

It is widely held in the energy-growth literature that higher economic growth usually comes at the cost of rapid environmental degradation [27]. The tradeoff between output growth and environmental quality is explained by the fact that more production needs more energy consumption and hence results in more emissions of hazardous gases. It implies that a reduction in energy poverty may lead to more environmental degradation. Therefore, the reduction in energy poverty without compromising the environmental is a of dire need worldwide. It can be achieved if the share of clean energy in the total energy mix increases over time. This takes us to the second dimension of our energy poverty index, which is clean energy. It mainly focuses on assessing the cost of energy poverty elimination in the form of environment degradation [4]. To this end, the previous literature shows that sustainability of environment is directly linked with quality of energy services [16,28].

In the construction of a clean energy index, the study relies upon six indicators. These indicators contain data regarding countries' reliance on renewable (clean) and non-renewable (dirty) energy. On the clean energy side, indicators such as alternative and nuclear energy [29], access to clean fuels and technologies for cooking, and share of renewable energy (hydro production) explain a country's preferences for clean energy over time [30]. On the other hand, indicators such as share of non-renewable energy, biofuels, and waste and overall $\mathrm{CO}_{2}$ emissions explain trends in dirty energy across different time periods [31]. Our particular focus on clean energy is also motivated by the fact that after the 21st conference on climate, held in Paris (COP21), the global community is putting more 
and more emphasis on environmental quality and reducing the reliance on dirty energy sources such as coal and fossil fuels (https:/ / ec.europa.eu/clima/policies/international/ negotiations / paris_en, accessed on 5 July 2021). Nevertheless, in Pakistan the scenario is completely different since the country has recently received a heavy inflow of foreign direct investment (FDI) in the energy sector under the umbrella of the China-Pakistan Economic Corridor (CPEC). The energy production from these CPEC related projects is mainly based on coal power plants containing the potential for more $\mathrm{CO}_{2}$ emissions.

\subsection{Energy Governance}

In developing countries, the existence of poor governance structure is a main root cause of energy poverty $[17,32,33]$. In the case of Pakistan, the main governance problems include compromised pricing-policies, high transmission, and distribution losses, switching from low-cost to high-cost energy generation projects, and limited capacity addition over the past many years. These factors play a significant role in determining the magnitude of energy poverty and energy insecurity [32]. Energy governance is mainly concerned with the provision of energy services at optimal cost and time [34]. Mainly, there are two aspects of energy governance. The first one is the institutional management while the second one corresponds to a combination of financial governance and management related governance which is basically linked with procurement and distribution sides of energy. Among all these elements, factors such as institutional and financial governance can be considered as exogenous since they capture the overall governance situation in Pakistan. In this case, the issue of energy governance is mainly related to the procurement and distribution of electricity [34]. Therefore, transmission and distribution losses at the aggregate level are used to capture the energy governance. According to World Bank statistics, total distribution and line losses of total electricity of Japan are nearly $4.4 \%$, while in Pakistan, they amount to nearly $17.5 \%$ of the total electricity generation. In the fiscal year 2007-2008 about $7.6 \%$ of total tax collection was spent on the provision of energy subsidies. The same spending reached to around $18 \%$ of total tax collection in the fiscal year 2011-2012 [35]. The growing share of subsidy of energy sector shows a poor governance structure of the country. In the present dimension, three indicators (having equal weights) are utilized as proxies of energy related governance. The first two indicators are linked with the domestic supply side governance while the last indicator shows the country's dependence on the imported energy. On this last indicator, the higher the country's dependence on imported energy, the higher will be the magnitude of any supply side shock on the domestic GDP growth [32]. While some studies in the existing literature focus on global energy governance issues [36], the present study addresses the same issue for an emerging economy, Pakistan.

\subsection{Energy Affordability}

In Table 1, the last dimension of EPI is energy affordability. The issue related to energy affordability is often considered a vague concept [37]. However, many authors argued that the concept of affordability has sound theoretical justifications [38]. According to theory, energy affordability implies a situation where a consumer or household can afford energy within the limits of his/her budget. In this context, energy affordability is mainly the problem of low-income households or low-income nations [7]. There exists an inverse relationship between energy affordability and energy poverty. Therefore, cost effective energy efficiency can reduce energy poverty [39]. Wang et al. [16] and Bollino and Botti [26] discuss energy affordability as a dimension of energy poverty. In the existing literature, mainly there are two approaches to measure the energy affordability: expenditure approach and consensual-based approach [26]. The first approach is a micro-based approach where the share of a household's income spent on energy items is taken as proxy of affordability. The second approach is more macro-based and here assessment of energy affordability is captured with some aggregate level proxy variables. In this study, energy affordability is measured using the second approach to keep this variable consistent with the remaining data set. The study takes three proxy variables to capture 
the energy affordability. The first variable is total four-wheel registration or motorization and the second is two-wheel registration. The motorization rate is number of passenger cars per 1000 inhabitants. Motorization rate is widely used as an indicator to compare the level of economic development across countries. While a two-wheel motorization is used as proxy for energy affordability of low-income and lower-middle income classes of society, a high rate of motorization shows high level of energy affordability. For instance, in Pakistan, the motorization rate is only 17 while in European Union (EU) it is 581 (see https: / / www.statista.com/statistics /610820/motorization-rate-in-selected-countries/, accessed on 5 July 2021). Additionally, total registered gas consumers are also used as a proxy indicator of energy affordability. Being a developing nation, our sample economy is continuously moving from biofuel to natural gas consumption. Hence, a shift towards more natural gas consumption would reflect an increase in energy affordability over time.

\subsection{Methodology}

As the study exploits seventeen indicators with different scales, directions, and properties, the first task is to descale these indicators to make a homogenous index of energy poverty. For this purpose, the following two formulae based on cost and benefit are used $[16,40]$.

$$
\begin{gathered}
\text { Benifit: } X_{t}^{i}=\frac{\operatorname{Max} x_{t}^{i}-x_{t}^{i}}{\operatorname{Max} x_{t}^{i}-\operatorname{Min} x_{t}^{i}}, \\
\text { Cost: } X_{t}^{i}=\frac{x_{t}^{i}-\operatorname{Min} x_{t}^{i}}{\operatorname{Max} x_{t}^{i}-\operatorname{Min} x_{t}^{i}},
\end{gathered}
$$

where capital $X_{t}^{i}$ is normalized value and $x_{t}^{i}$ is actual value of $x$ variable at year $t$, and ' $i$ ' represents the indicators (i.e., $i=1,2, \cdots, 17)$. The modified variable $X_{t}^{i}$ is dimension and scale free and its value lies between zero to one. After the normalization of indicators, the next task is to assign the weight to each indictor at the first stage and then each dimension at the second stage. There are diverse views regarding the allocation of weights depending upon the ultimate objective of composite measurement [26,29]. According to Greco et al. [41], assigning the weight to indicators and dimensions is an objective approach. After allotting the equal weights, the linear aggregation method is used for final index value. Due to its advantages in the form of simplicity, transparency and accessibility, the equal weight method is used in different studies [41,42]. The equal weight strategy (each dimension (i.e., 0.25) as well as indicators) is used in the present study to avoid bias. Assigning the equal weights means these indicators would contribute equally to the energy poverty. For example, our first dimension, energy services, comprises five indicators, each having the same weight of 0.2 . The rest of the three dimensions have six, three, and three, respectively, and each having weight accordingly. This index can also be used to compare the real situation of energy poverty over time. This newly developed index uses positive and negative indicators to capture the net effect, where each dimension explains different aspect of energy poverty.

The details of the four dimensions and their respective indicators are shown in Table 2. The last column of this table depicts the correlation values between each dimension and energy poverty index (EPI). The value of the correlation coefficient between energy services and EPI is 0.92 , implying a very strong positive association between these two. The value of the coefficient of correlation between clean energy and EPI is about 0.61, which shows a good association between renewable energy sources and energy poverty. However, the linear association between energy governance indicators with the EPI is in the moderate zone, although the energy governance has had strong dynamics for other dimensions as well as for EPI [32]. Finally, our fourth dimension, energy affordability, exhibits the strongest correlation with EPI, and the value of the correlation coefficient amounts to 0.95 in this case. 
Table 2. Weight distributions and correlation results between index and dimensions.

\begin{tabular}{|c|c|c|c|}
\hline & Dimensions & Indicators & $\begin{array}{l}\text { Correlation between } \\
\text { Dimension and EPI }\end{array}$ \\
\hline \multirow{17}{*}{ 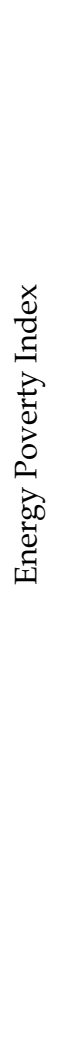 } & \multirow{5}{*}{ 1/4(Energy Services) } & $1 / 5$ (Access to electricity, rural (\% of rural population)) & \multirow{5}{*}{0.92578} \\
\hline & & 1/5(Domestic crude oil production (TOE)) & \\
\hline & & 1/5(Total energy supply by all sources in KTOE) & \\
\hline & & $1 / 5$ (Access to electricity ( $\%$ of urban population)) & \\
\hline & & 1/5(Energy use (kg of oil equivalent)) & \\
\hline & \multirow{6}{*}{ 1/4(Clean Energy) } & $\begin{array}{c}\text { 1/6(Alternative and nuclear energy ( } \% \text { of total } \\
\text { energy use) })\end{array}$ & \multirow{6}{*}{0.60597} \\
\hline & & $1 / 6\left(\mathrm{CO}_{2}\right.$ emissions (metric tons per capita)) & \\
\hline & & $\begin{array}{l}1 / 6 \text { (Access to clean fuels and technologies for cooking } \\
\text { (\% of population) })\end{array}$ & \\
\hline & & 1/6(Share of non-renewable (coal)) & \\
\hline & & 1/6(Share of renewable energy (hydro production)) & \\
\hline & & 1/6(Biofuels and waste KTOE) & \\
\hline & \multirow{3}{*}{ 1/4(Energy Governance) } & $\begin{array}{l}\text { 1/3(Transmission and distribution losses (electricity } \\
\text { billion kwh)) }\end{array}$ & \multirow{3}{*}{0.460029} \\
\hline & & $1 / 3($ Generation billion $\mathrm{KW})$ & \\
\hline & & 1/3(Energy imports, net (\% of energy use)) & \\
\hline & \multirow{3}{*}{ 1/4(Energy Affordability) } & 1/3(Number of consumers of gas) & \multirow{3}{*}{0.95205} \\
\hline & & 1/3(Registered four-wheels out of 1000 people) & \\
\hline & & 1/3(Registered two-wheels for 1000 people) & \\
\hline
\end{tabular}

Generally, factor analysis methods are used to find internal reliability of an index. A simple correlation can also be used to capture the reliability of a composite variable. Exploratory factor analysis (EFA) and confirmatory factor analysis (CFA) are two other methods to find the reliability through the covariances [43]. Principal component analysis (PCA) is by default similar like EFA method which is not considered as a good method because it does not estimate the measurement errors [44]. It is prerequisite condition for CFA that the variables under consideration should be drawn from the literature [45].

Standardize form of CFA of four dimension with EPI is provided in following Table 3. Here EPI is a latent variable, and four dimensions are observed variables. The probability values of two factor loadings are 0.00 and remaining two values are less than 0.1 level of confidence. At $10 \%$ level of significance, all factor loadings are statistically significant, and their magnitudes need to be discussed. The standardized factor loading of energy services availability and energy affordability are 0.89 and 0.98 , respectively, which are categorized as meritorious and marvelous [46]. Other things held constant; a one standard deviation increase in energy services availability leads to 0.894 standard deviation increase in EPI, and so on. Clean energy and energy governance did not have relatively strong factor loadings as their coefficients have low magnitudes. However, these two loading factors have sound theoretical reliability. Clean energy and energy governance are related to long-run path sustainability and may be consistent with energy poverty in other developing societies as well. 
Table 3. Confirmatory factor analysis.

\begin{tabular}{|c|c|c|c|c|}
\hline & Coeff & OIM S.E & $Z$ value & $\mathbf{P}>|\mathbf{z}|$ \\
\hline Energy Services <- EPI & 0.89 & 0.07 & 12.33 & 0.00 \\
\hline Constant & 1.75 & 0.30 & 5.82 & 0.00 \\
\hline Clean Energy <- EPI & 0.46 & 0.16 & 2.70 & 0.01 \\
\hline Constant & 7.53 & 1.02 & 7.14 & 0.00 \\
\hline Energy Governance <- EPI & 0.29 & 0.15 & 1.93 & 0.08 \\
\hline Constant & 4.47 & 0.63 & 7.14 & 0.00 \\
\hline Energy Affordability <- EPI & 0.98 & 0.07 & 13.84 & 0.00 \\
\hline Constant & 2.12 & 0.34 & 6.23 & 0.00 \\
\hline Var(e. Energy Services) & 0.20 & 0.13 & $N A$ & $N A$ \\
\hline Var(e. Clean energy) & 0.80 & 0.14 & $N A$ & $N A$ \\
\hline Var(e. Energy Governance) & 0.92 & 0.09 & $N A$ & $N A$ \\
\hline Var(e. Energy Affordability) & 0.02 & 0.14 & $N A$ & $N A$ \\
\hline
\end{tabular}

The main drawback of CFA is its assumption of a normal distribution of the underlying dataset [46]. However, the time series data are not normally distributed due to time trend and inertia properties, therefore the extraction of weights in such situations may result in bias.

Estimated variance of the measurement errors for each dimension are given in the last column. Again, clean energy and energy governance contains more measurement errors relative to the energy services availability and energy affordability.

\subsection{Energy Poverty}

The following dynamic equation is used to calculate the EPI by assigning equal weights. According to Culver [47], the International Energy Agency developed the Energy Development Index (EDI) by calculating an evenly-weighted average of three normalized components.

$$
(\text { EPI })_{t}=1 / 4\left\{(\text { Energy Services })_{t}+(\text { Energy Governance })_{t}+(\text { Clean Energy })_{t}+(\text { Energy Affordability })_{t}\right\}
$$

The values of EPI lie between zero and one. A low value indicates reduction in energy poverty and vice versa. The evolution of energy poverty index over time is shown in Figure 1. As can be noticed, the Pakistan economy observed improvements on the energy poverty fronts over the entire sample period. Nevertheless, the speed of reduction was slow and experienced upward movements on several occasions. We can divide this whole period into decade-long sub-periods and link the energy poverty with the political instability in Pakistan. In the first decade comprising the period 1990-1999, the country experienced political instability because four democratic governments were ousted from office before the completion of their constitutional tenure. As a result of this political instability, all the macroeconomic indicators including energy poverty observed worse trends. The situation stabilized temporarily in 1999 when the military dictator Pervaiz Musharraf assumed the office of chief executive. During the period 1999 to 2007, the country experienced overall political stability, although the law-and-order conditions started deteriorating from 2006 onwards due to terrorist activity. This diverted the resources from economic development to defense and hence the energy poverty increased again. At the same time, oil prices at the global level tripled within an 18 months period, which caused a 36\% increase in the import bill and increased the intensity of energy poverty [9]. The next important event was the 2008 general elections and the transition of regime. Following this successful transition, the country has been experiencing an improvement in energy poverty alleviation, nonetheless, the speed is relatively slow due to both external (i.e., international financial crisis and episodes of oil price hikes) and internal (i.e., weak economic growth of Pakistan, terrorism and increasing public debt) factors. The latest increase in the EPI over the period of 2016-2017 can mainly be linked with the domestic factors. 


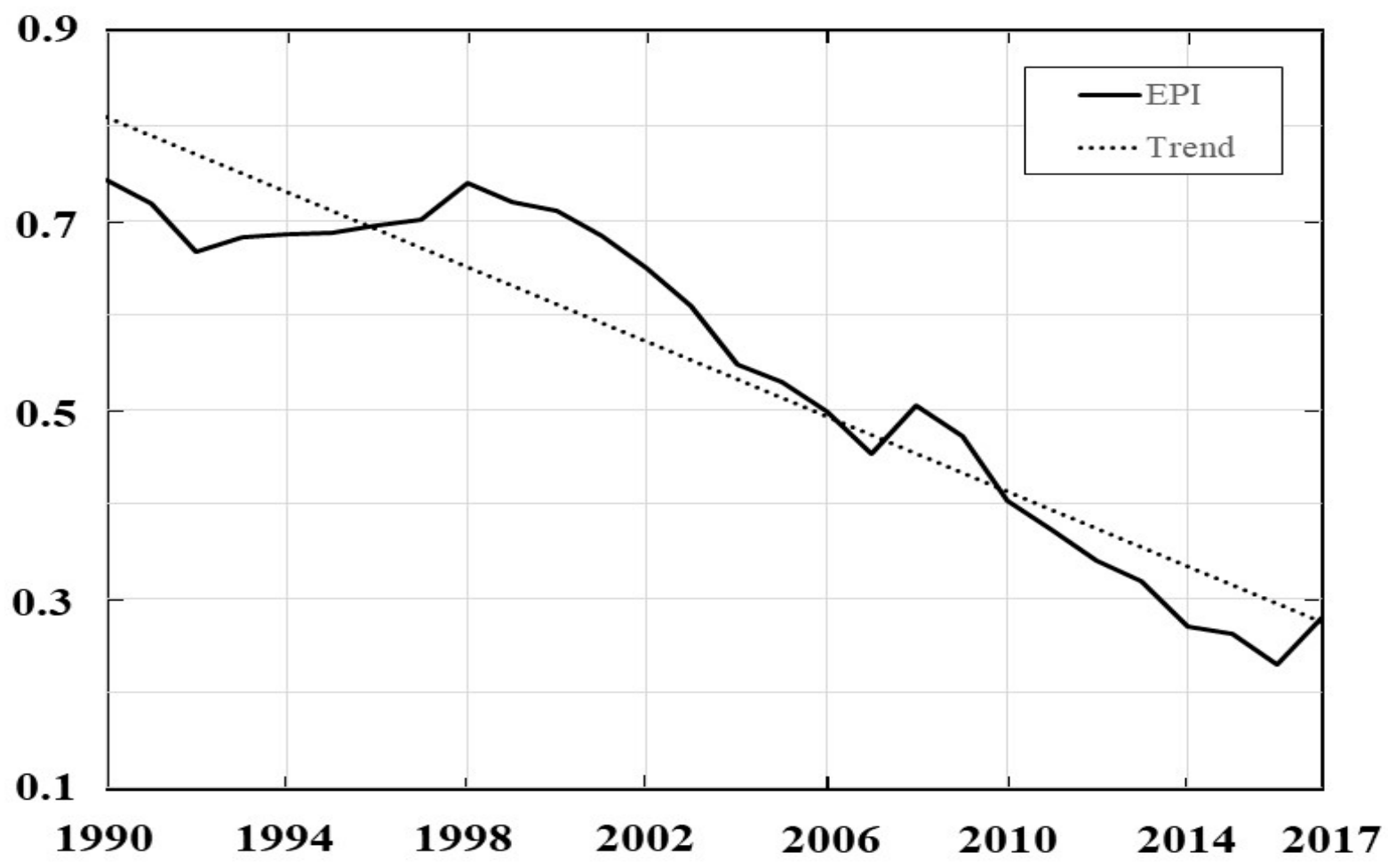

Figure 1. Evolution of energy poverty index over time.

\subsubsection{Energy Services and Energy Poverty}

Energy services at affordable prices are considered inevitable for long-run economic growth, productivity, and welfare. The provision of energy services also determines energy intensity or energy conservation. Efficient energy services availability at affordable prices is also important for poverty reduction since this involves both operating costs and investment [48]. In order to analyze the relationship between energy poverty and energy services, Figure 2 plots these two variables over the selected sample period. Here again, the decade of the 1990s observed weak performance in the provision of energy services due to the factors detailed above. The outcome of this underinvestment was a continuous increase in energy poverty during the first decade. The comparison of dotted and thick lines also shows that during the 1990s, energy services did not contribute to energy poverty reduction. The trend reversed from 2000 onward, illustrating a strong correlation between energy poverty and energy services. Therefore, the role of energy services in energy poverty reduction increased in the last two decades.

\subsubsection{Clean Energy and Energy Poverty}

Although the provision of cheap and uninterrupted energy supply is a pre-condition for output growth of modern economies, in recent decades there has been particular attention to the provision of clean energy. Figure 3 summarizes the relationship between clean energy and energy poverty in the case of Pakistan. The graph shows a very volatile behavior of the clean energy indicator over time. Overall, the share of clean energy in the total energy mix remained satisfactory until 2008. However, starting from 2008, the Pakistan economy entered into an era of chronic energy crisis that forced the successive governments to opt for short-term solutions, including energy production from national and international independent power producers (IPPs), working on imported oil. The real cost of such policies is that climate change is continuously increasing at a compounding rate. The recent trend in this degradation came after the start of CPEC-related energy projects that mainly rely on imported coal for the provision of electricity. The increasing 
trend of the clean energy indicator also presents an alarming situation for the sustainable development of the Pakistan economy.

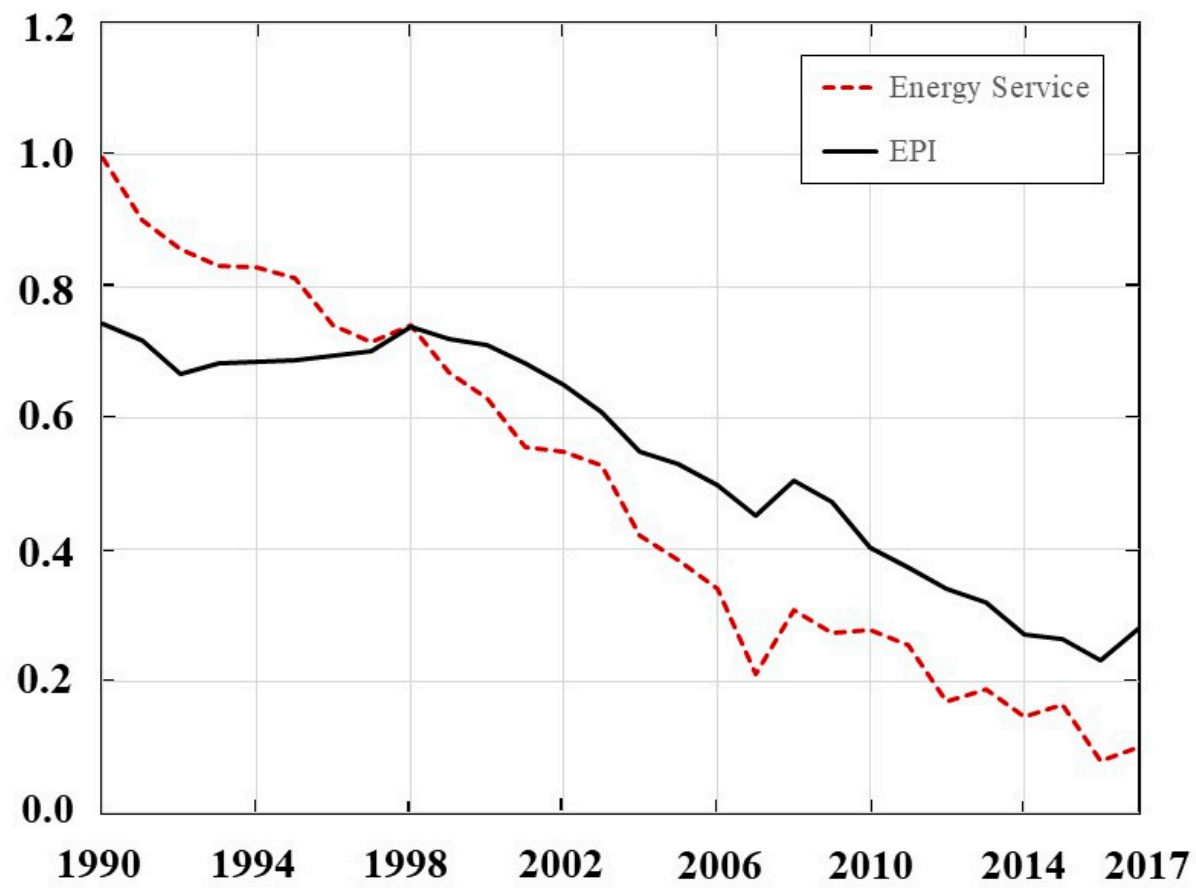

Figure 2. Energy services and energy poverty.

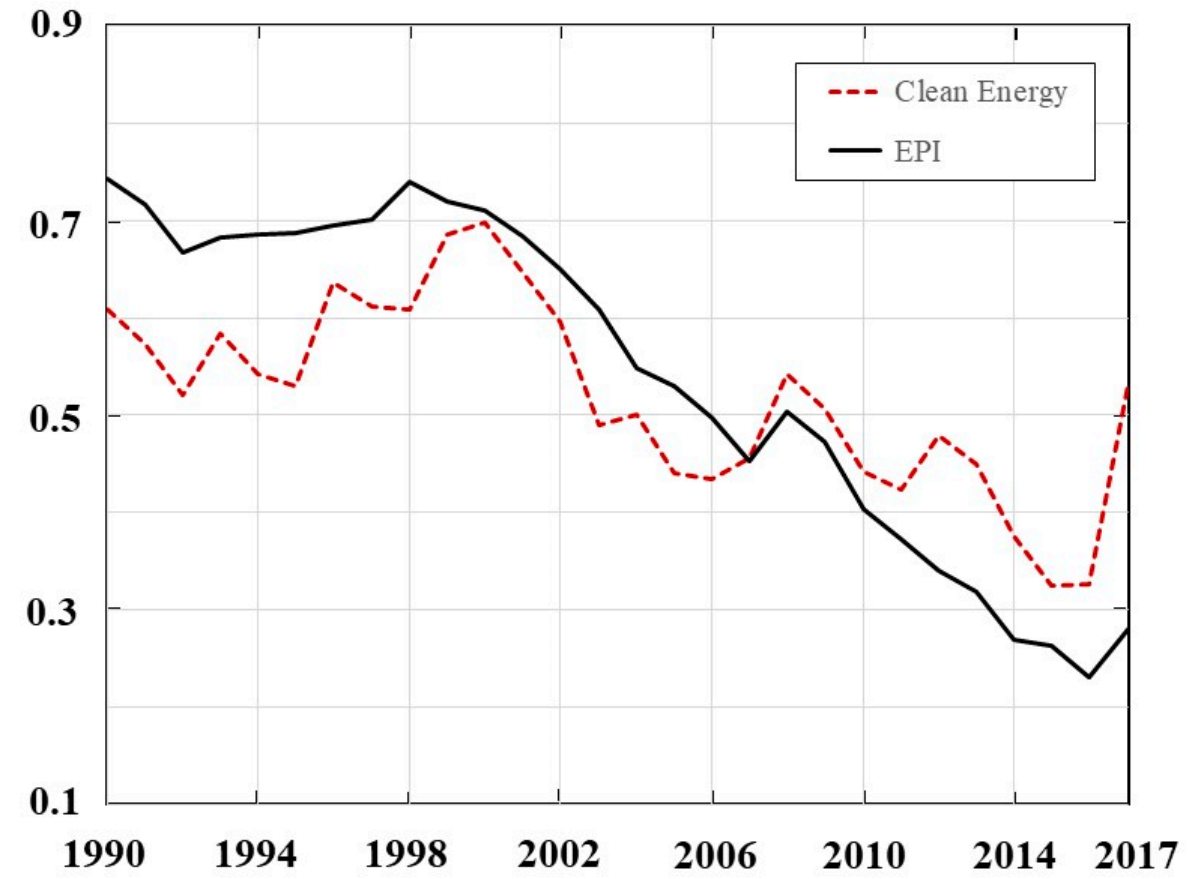

Figure 3. Clean energy and energy poverty.

\subsubsection{Energy Governance and Energy Poverty}

Our next task is to discuss the governance performance of the energy sector of Pakistan and its relationship with our proposed EPI. The energy governance implies the overall performance of all those institutions that are considered as movers and shakers of energy in Pakistan. The situation of energy governance is not substantially different from the overall governance condition of our selected economy [40]. Figure 4 shows the overall condition 
of governance indicator during the selected sample period and its correlation with EPI. Consistent with the previous indicators, energy governance shows fluctuations over time. The correlation between energy governance and EPI is strongest in the middle decade of the sample period compared to the first and third decades, again explaining the positive role of political stability on the energy governance and hence energy poverty reduction.

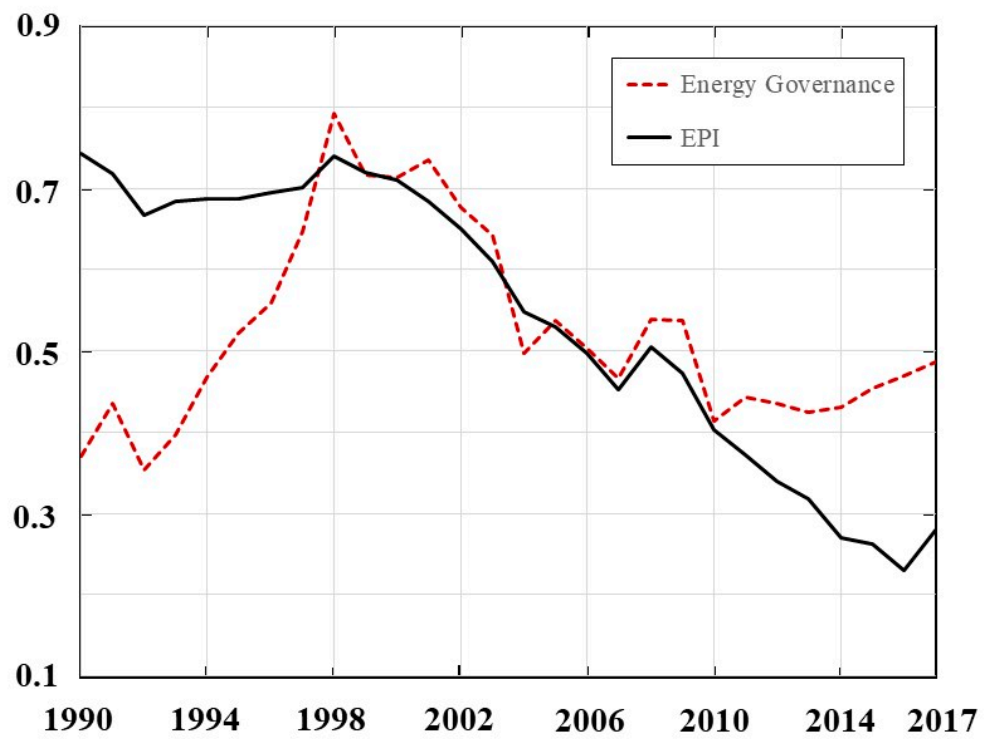

Figure 4. Energy governance and energy poverty.

\subsubsection{Energy Affordability and Energy Poverty}

Our last dimension of EPI, energy affordability, calculated by our proposed method, is depicted in Figure 5. This indicator shows an encouraging trend for Pakistan since energy affordability of the society continues to increase during the selected time period. This can be due to an increasing demand for wheels in the economy coming from factors such as changes in preferences, better road conditions, improved living standards and a rapid population growth. Furthermore, the country is also experiencing the process of rapid urbanization, implying more demand for vehicles.

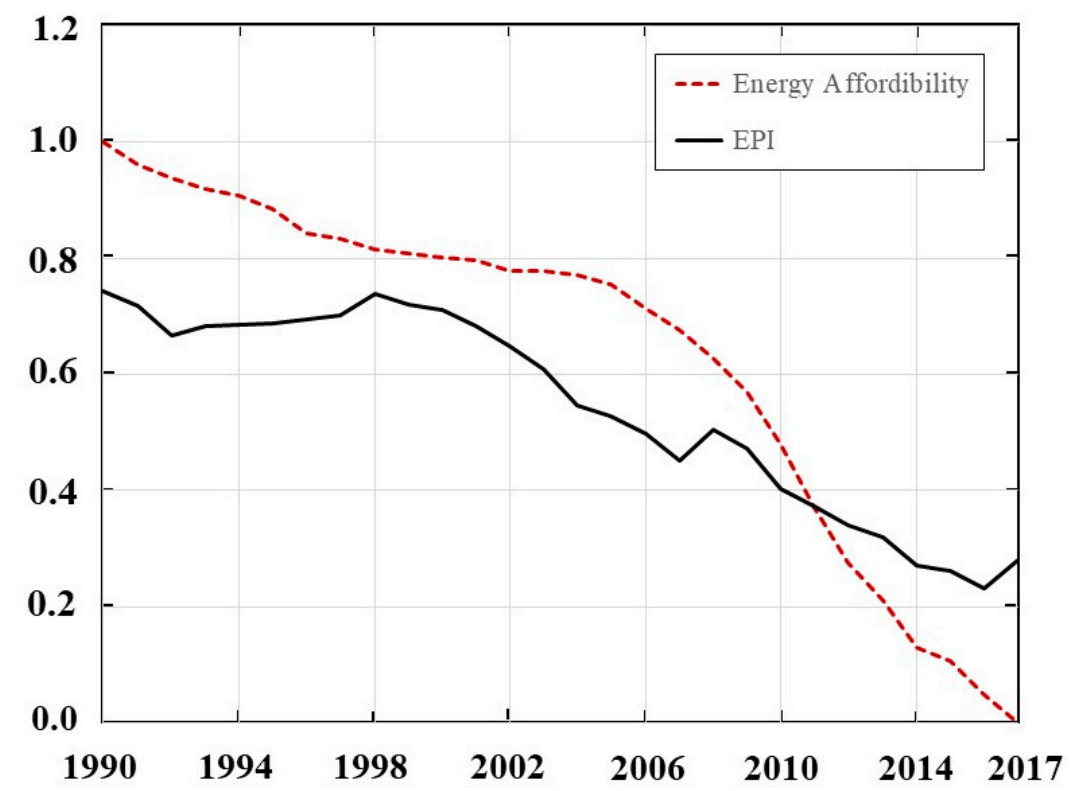

Figure 5. Energy affordability and energy poverty. 


\section{Model and Estimation Procedure}

This section tries to econometrically estimate the impact of energy poverty (EPI) on economic growth of Pakistan. Starting from the seminal work by Solow [49], the growth in the literature has persistently highlighted the contribution of labor and capital for economic growth. Some recent developments in this literature acknowledge the relevance of various economic, social, technological, and demographic factors for countries' economic development [50-52]. Based on these developments, the following Cobb-Douglas production function type econometric model is proposed to analyze the significance of energy poverty along with the other neoclassical factors on economic growth of Pakistan [53]:

$$
Y_{t}=A \times E P_{t}^{\alpha_{1}} H C_{t}{ }^{\alpha_{2}} K_{t}{ }^{\alpha_{3}} e^{u_{t}}
$$

where $Y_{t}$ shows economic growth over time, $A$ is total factor productivity, $E P_{t}$ presents energy poverty, $H C_{t}$ is for human capital, and $K_{t}$ captures the capital stock over time. The logarithmic form of Cobb-Douglas production function provides a deterministic linear relationship between independent and dependent variables of regression. Theoretically, the accuracy of prediction based on linear regression is relatively higher than the nonlinear regression. Since the above model is non-linear with respect to parameters, the study conducts the following logarithmic transformation to make it log-linear.

$$
\ln Y_{t}=\alpha_{0}+\alpha_{1} \ln E P_{t}+\alpha_{2} \ln H C_{t}+\alpha_{3} \ln K_{t}+u_{t} .
$$

One of the advantages of using a double-log model is that it provides elasticities in form of estimated parameters. For instance, in the above case, the elasticity of economic growth with respect to energy poverty can be expressed in the following way.

$$
\varepsilon_{Y, E P}=\alpha_{1}
$$

The hypothesized sign of $\alpha_{1}$ should be negative in the present study, illustrating the fact that a reduction in energy poverty accelerates economic growth. Total gross value added is used as proxy of economic growth and treated as the dependent variable of the model [54]. For the independent variables, the study uses the data of gross fixed capital formation as proxy of physical capital accumulation, whereas the data of average years of schooling age 15 and above is used as a proxy indicator of human capital (study extends the data of "Average years of total schooling, age 15+, total" by utilizing the methodology of Barro-Lee) $[55,56]$. In neo-classical growth theories labor is considered as a source of growth while in new growth theories human capital is treated as the engine of growth. Data of these three variables are collected from the World Development Indicators (WDI) and Education Statistics of World Bank [57].

For the estimation of this multivariate energy poverty and economic growth model, our empirical strategy comprises four steps of investigation: the first step presents the stationarity properties of the selected variable; the second step conducts cointegration tests; the third step retrieves short-run and long-run estimates of the variable; and the final step presents the variance decomposition matrices of economic development and energy poverty variables. 


\section{Results and Discussion}

\subsection{Stationarity Tests}

In order to test the unit root properties of the data series, the study relies upon two different stationarity tests, including Augmented Dickey-Fuller (ADF) [58] and Phillips and Parron (PP) tests [59]. The results of these tests are presented in Table 4. As can be viewed from the test results, all the variables are non-stationary at level and stationary at first difference. In $I(1)$ case with a single cointegrating vector, one simply regresses one of the variables onto contemporaneous levels of the remaining variables, leads and lags of their first differences, and a constant, using either ordinary or generalized least squares. The resulting "dynamic OLS" (respectively, GLS) estimators are asymptotically equivalent to the Johansen/Ahn-Reinsel estimator [60].

Table 4. ADF and PP test of unit root.

\begin{tabular}{|c|c|c|c|c|c|c|c|c|c|}
\hline \multirow[t]{3}{*}{ Variable } & \multicolumn{4}{|c|}{ Augmented Dickey-Fuller (ADF) Test } & \multicolumn{4}{|c|}{ Phillips Perron (PP) Test } & \multirow[t]{3}{*}{ Remarks } \\
\hline & \multicolumn{2}{|c|}{ Intercept } & \multicolumn{2}{|c|}{ Intercept with Trend } & \multicolumn{2}{|c|}{ Intercept } & \multicolumn{2}{|c|}{ Intercept with Trend } & \\
\hline & Level & 1st Diff. & Level & 1st Diff. & Level & 1st Diff. & Level & 1st Diff. & \\
\hline LY & -0.11 & $-3.56^{* *}$ & -2.88 & $-3.46^{* *}$ & -0.32 & $-3.56^{* * *}$ & -2.14 & $-3.47^{* *}$ & $I(1)$ \\
\hline LHC & -1.1 & $-4.98 *$ & -0.99 & $-5.14 *$ & -1.15 & $-4.98 *$ & -1.02 & $-5.16^{*}$ & $I(1)$ \\
\hline LEP & 0.19 & $-5.05 *$ & -1.73 & $-5.15^{*}$ & 0.21 & $-5.07 *$ & -1.72 & $-5.14 *$ & $I(1)$ \\
\hline LK & -0.26 & -4.31 * & -1.80 & $-4.23^{* *}$ & -0.31 & $-4.29 *$ & -1.96 & $-4.21^{* *}$ & $I(1)$ \\
\hline
\end{tabular}

Notes: (a) The critical values of unit root test (ADF and PP) are $-4.33,-3.58$, and -3.22 (with trend) and $-3.69,-2.97$, and -2.62 (without trend), respectively, at $1 \%, 5 \%$, and $10 \%$ significance levels. (b) ${ }^{*}, * *$, and ${ }^{* * *}$ denote significance at $1 \%, 5 \%$ and $10 \%$ levels, respectively.

\subsection{Johansen Cointegration Test}

All variables of the model are integrated at first difference $I(1)$, so cointegration analysis is conducted using cointegration technique of multivariate to test the long-run relationship among variables [61]. An unrestricted vector autoregressive model (VAR) is estimated by considering all variables as endogenous. For dynamic analysis, optimal lags are selected through different criterions and most of the criterions suggest two lags are suitable. The calculated statistics for both trace and maximum eigenvalues are presented in Table 5. These findings confirm the existence of a long-run relationship between income, human capital, physical capital, and energy poverty of the selected sample economy. These results are consistent with the findings of Amin et al. [52], who support the existence of a cointegration relationship between energy poverty and economic development for South Asian economies.

Table 5. Result of cointegration test.

\begin{tabular}{|c|c|c|c|c|c|c|c|c|}
\hline \multicolumn{5}{|c|}{$\begin{array}{l}\text { Unrestricted Cointegration Rank Test } \\
\text { (Trace) }\end{array}$} & \multicolumn{4}{|c|}{$\begin{array}{l}\text { Unrestricted Cointegration Rank Test } \\
\text { (Maximum Eigenvalue) }\end{array}$} \\
\hline $\begin{array}{l}\text { Hypothesized } \\
\text { No. of CE(s) }\end{array}$ & Eigenvalue & $\begin{array}{c}\text { Trace } \\
\text { Statistics }\end{array}$ & $\begin{array}{l}0.05 \text { Critical } \\
\text { Value }\end{array}$ & $p$-Value & Eigenvalue & $\begin{array}{l}\text { Max-Eigen } \\
\text { Statistics }\end{array}$ & $\begin{array}{l}0.05 \text { Critical } \\
\text { Value }\end{array}$ & $p$-Value \\
\hline None & 0.71 & 53.44 & 47.86 & 0.014 * & 0.70 & 32.93 & 27.58 & 0.009 * \\
\hline At Most 1 & 0.40 & 20.51 & 29.79 & 0.391 & 0.39 & 13.59 & 27.13 & 0.390 \\
\hline At Most 2 & 0.18 & 6.91 & 15.49 & 0.588 & 0.18 & 5.39 & 14.26 & 0.690 \\
\hline At Most 3 & 0.06 & 1.51 & 3.84 & 0.210 & 0.05 & 1.51 & 3.84 & 0.210 \\
\hline
\end{tabular}

Note: * indicates significance at $5 \%$ level. 


\subsection{Long-Run and Short-Run Results}

Once the cointegration is established, the next task is to get the long-run and short-run impact of human capital, physical capital, and energy poverty on economic growth of the Pakistan economy. These outcomes are reported in Table 6. It is worth mentioning that the long-run coefficients of the variables are normalized and hence the signs are reversed [56]. For instance, the first coefficient of energy poverty implies that a $1 \%$ increase in energy poverty will lead to a $0.052 \%$ decrease in economic growth [3]. Similarly, an increase in human and physical capital accumulation by $1 \%$ will lead to $0.876 \%$ and $0.132 \%$ increase in the long-run output growth. In short-run analysis, all variables are used in differenced form or here optimal lag one is selected. All short-run coefficients are also treated as short-run elasticities. The short-run elasticities are different than the long-run. However, in the short-run, economic growth is only explained by its own changes in the previous period. The coefficient of the error correction term is -0.37 , showing that it takes around three years before deviation in the short-run values converge to the long-run equilibrium. These results are consistent with Amin et al. [52], who reported a growth inhibiting effect of energy poverty for their selected South Asian economies.

Table 6. Results of long-run and short-run analysis.

\begin{tabular}{lll}
\hline \multicolumn{1}{c}{ Dependent Variable: Income } & & Coefficient \\
\hline Long-term elasticities & & $t$ \\
\hline LEP & $0.052^{* * *}$ & 2.683 \\
LHC & $-0.876^{* * *}$ & -30.899 \\
LK & $-0.132^{* * *}$ & -6.837 \\
Short-term elasticities & & -1.88 \\
ECT & $-0.370^{*}$ & 2.42 \\
$\Delta($ LY(-1)) & $0.558^{* * *}$ & -0.08 \\
$\Delta($ LEP $)$ & -0.004 & -0.48 \\
$\Delta($ LHC $(-1))$ & -1.106 & 0.19 \\
$\Delta($ LK(-1)) & 0.006 & $p$-value \\
\hline Diagnostic tests & Test statistic & 0.38 \\
Jarque-Bera normality (joint) & 8.61 & 0.54 \\
Breusch-Godfrey LM test & 14.77 & \\
\hline
\end{tabular}

Note: ${ }^{*}$ and ${ }^{* * *}$ denote significance at $1 \%$ and $10 \%$ levels, respectively.

\subsection{Variance Decomposition Analysis}

The last part of the results comprises variance decomposition of both the variables of interest, economic growth and energy poverty $[62,63]$. These results are shown in Table 7. For both the variables of interest, the decomposition of shock to any variable stretches over the period of ten years. As depicted by the variance decomposition analysis, a shock to income accounts for whole variance of income in the first year. However, after ten years, the share of income goes down to nearly $82 \%$ while energy poverty becomes the second most important factor by explaining just over $8 \%$ variation in income. The share of human capital remains around $2.36 \%$, whereas physical capital accounts for $7.68 \%$ variation in income after 10 years. A similar pattern can be observed for energy poverty where, in the first 10 years, almost 100 variations in this variable are explained by itself. However, after 10 years the effect of shock to energy poverty on the energy poverty goes down to $70.52 \%$ whereas income accounts for $25.89 \%$ of changes in energy poverty. The share of human and physical capital accumulation in the variability of energy poverty is negligible even after 10 years. For both these variables, the respective share remains $2.43 \%$ and $0.17 \%$ for the variability of energy poverty in Pakistan. 
Table 7. Results of variance decomposition.

\begin{tabular}{|c|c|c|c|c|c|}
\hline \multicolumn{6}{|c|}{ (a) Variance Decomposition of GDP } \\
\hline Period & S.E. & LY & LEP & LHC & LK \\
\hline 1 & 0.02 & 100.00 & 0.00 & 0.00 & 0.00 \\
\hline 2 & 0.03 & 96.24 & 0.96 & 0.55 & 2.26 \\
\hline 3 & 0.04 & 89.30 & 3.92 & 1.51 & 5.27 \\
\hline 4 & 0.04 & 85.06 & 6.19 & 2.02 & 6.74 \\
\hline 5 & 0.05 & 83.61 & 7.08 & 2.17 & 7.14 \\
\hline 6 & 0.05 & 83.24 & 7.33 & 2.20 & 7.23 \\
\hline 7 & 0.06 & 82.9 & 7.49 & 2.24 & 7.33 \\
\hline 8 & 0.06 & 82.56 & 7.69 & 2.28 & 7.47 \\
\hline 9 & 0.06 & 82.20 & 7.88 & 2.33 & 7.59 \\
\hline 10 & 0.07 & 81.94 & 8.02 & 2.36 & 7.68 \\
\hline \multicolumn{6}{|c|}{ (b) Variance Decomposition of LEP } \\
\hline Period & S.E. & LY & LEP & LHC & LGFC \\
\hline 1 & 0.08 & 0.79 & 99.21 & 0.00 & 0.00 \\
\hline 2 & 0.11 & 5.32 & 92.90 & 1.61 & 0.17 \\
\hline 3 & 0.14 & 12.50 & 83.92 & 3.12 & 0.46 \\
\hline 4 & 0.17 & 18.39 & 77.94 & 3.33 & 0.34 \\
\hline 5 & 0.19 & 21.60 & 74.84 & 3.27 & 0.30 \\
\hline 6 & 0.20 & 23.12 & 73.34 & 3.27 & 0.27 \\
\hline 7 & 0.22 & 23.99 & 72.45 & 3.32 & 0.24 \\
\hline 8 & 0.23 & 24.71 & 71.70 & 3.37 & 0.21 \\
\hline 9 & 0.25 & 25.36 & 71.05 & 3.40 & 0.18 \\
\hline 10 & 0.26 & 25.89 & 70.52 & 3.42 & 0.17 \\
\hline
\end{tabular}

\section{Conclusions}

Energy is considered a lifeline for economies in the modern era. An economy working with a subsistence level of energy will be the one having subsistence level of economic development [52,64-67]. Hence, energy poverty becomes an economic issue, and a growing level of energy poverty can lead to several social conflicts within the energy scarce societies. Likewise, dependence on polluted energy to solve the energy poverty problem can trigger environmental problems and threaten the sustainable development of the country. Keeping in view all these aspects of energy poverty, the issue has attracted a lot of attention from researchers and international organizations working on the subject.

Against this backdrop, this study develops a comprehensive index of energy poverty by classifying it into four dimensions, energy services availability, clean energy, energy governance and energy affordability. Furthermore, these four dimensions are based on seventeen indicators. The study then investigated the relationship between energy poverty and economic growth by utilizing time series data of the Pakistan economy from 1990 to 2017. The main outcomes of this study can be summarized as follows: first, over the selected sample period, the Pakistan economy is trying to make advancements on its journey from an energy poor to an energy rich country. Second, the availability of energy services is also in its transitional phase due to intensive electrification over the sample period. Third, improvement in EPI is negatively linked with the provision of clean energy supply in the case of Pakistan. This implies that although the country's energy supply has seen improvements, it still faces serious threats on sustainable environmental quality fronts because the share of dirty energy in the total energy mix is increasing rapidly. Fourth, poor energy governance is also a hurdle in solving the issue of energy poverty. Poor energy governance is mainly the outcome of overall political uncertainty in the country. Fifth, there is a statistically significant relationship between energy poverty and economic growth in the short-run as well in the long-run. Moreover, an exogenous shock leading to energy poverty reduction also improves the growth performance of the selected economy. 
Based on results, the study concludes that energy poverty is a serious threat for the sustainable growth of Pakistan, being as it is the availability of energy at affordable prices that can rescue Pakistan's economy from the vicious cycle of poverty. Energy enrichment can be considered a modern 'big-push' for economic development. In order to experience such big push, the country, however, needs a well-designed assistance program that can break the technological, social, economic, and energy governance related bottlenecks [13]. Lastly, our findings have sound implications for the improvements of energy governance and clean energy for Pakistan and for the other developing countries in general. On the basis of key findings, the present study could be helpful to set targets for each dimension of the present energy poverty index. Without substantial improvements on these two fronts, developing countries like Pakistan can never reap the benefits of economic growth by merely inviting FDI into their polluted energy production sectors. Policymakers should make appropriate polices and efficient institutional framework to mobilize the FDI in large scale renewable energy projects that have lower running costs and better shares in clean energy. In addition, in the short-run, both LPG and LNG can also be good options due to their efficiency and low combustion. These short-run and long-run strategies guarantee the availability of clean and modern energy services at affordable prices. Moreover, there needs to be a comprehensive coordination among social, political, institutional, and technological factors that essentially fall outside the energy sector.

The government of Pakistan, in its vision 2030, aims to increase the energy availability at affordable prices. It wants to increase the generation capacity of electricity by 45000 MW and commits that $90 \%$ of the total population that consumes electricity will meet the 7th goal of sustainable development of the United Nations Development Programme (UNDP). However, the results of this study suggest that the goals of energy generation and availability of energy can be achieved only if the government focuses on energy governance and clean energy contents into the energy mix.

Concerning the main limitations of this study, our empirical approach to measuring energy poverty is incapable of capturing the headcount poverty ratio and degree of energy poverty of a society. The reliability and efficiency of our results may differ from the studies using other demand- and supply-side indicators. Many other specifications to measure energy poverty are available in the literature, therefore the sensitivity of our results with respect to specification changes can also be tested on empirical grounds. Finally, the future studies can also use our energy poverty index to find out its impact on other macroeconomic indicators of Pakistan. Lastly, a sectoral level or disaggregate analysis can also be performed on the same pattern.

Author Contributions: All the authors contributed to the entire process of writing this paper. S.U. and M.K. conceived the idea and designed the structure of this paper, S.U. collected and examined the data and M.K. devised the methodology, M.K. wrote the draft of Sections 2 and 3, S.U. wrote Sections 4 and 5, S.-M.Y. wrote Section 1 and reviewed and edited the manuscript and performed a final revision of the entire paper. All authors have read and agreed to the published version of the manuscript.

Funding: This work was supported by the Ministry of Education of the Republic of Korea and the National Research Foundation of Korea (NRF-2020S1A5B8103268). This work was supported by a 2-Year Research Grant of Pusan National University.

Institutional Review Board Statement: Not applicable.

Informed Consent Statement: Not applicable.

Data Availability Statement: All sample data sets have been downloaded from Thompson Reuters Eikon. Restrictions apply to the availability of these data, which were used under license for this study. Data are available at the World Development Indicators of World Bank (https:// datatopics.worldbank.org/world-development-indicators, accessed on 5 July 2021), International Energy Agency (https: / / www.iea.org, accessed on 5 July 2021), Pakistan Energy Yearbook (https: / / www.hdip.com.pk/energy-yearbook.php, accessed on 5 July 2021) and Pakistan Bureau of Statistics (https: / /www.pbs.gov.pk, accessed on 5 July 2021). 
Conflicts of Interest: The authors declare no conflict of interest.

$\begin{array}{ll}\text { Abbreviations } \\ \text { COP21 } & \text { 21st conference on climate held in Paris } \\ \text { CPEC } & \text { China-Pakistan Economic Corridor } \\ \text { EPI } & \text { Energy poverty index } \\ \text { EU } & \text { European Union } \\ \text { FDI } & \text { Foreign direct investment } \\ \text { IEA } & \text { International Energy Agency } \\ \text { PBS } & \text { Pakistan Bureau of Statistics } \\ \text { PEB } & \text { Pakistan Energy Year Book } \\ \text { SDGs } & \text { Sustainable Development Goals } \\ \text { TOE } & \text { Ton of oil equivalent } \\ \text { UNDP } & \text { United Nations Development Programme } \\ \text { WDI } & \text { World Development Indicators }\end{array}$

\section{References}

1. Bauer, P.T. The vicious circle of poverty. Weltwirtschaftliches Archiv 1965, 95, 4-20. Available online: https://www.jstor.org/stable/ pdf/40436342.pdf (accessed on 27 October 2018).

2. Buzar, S. Energy Poverty in Eastern Europe: Hidden Geographies of Deprivation. Routledge 2007. Available online: https://www. routledge.com/Energy-Poverty-in-Eastern-Europe-Hidden-Geographies-of-Deprivation/Buzar/p/book/9780754671305 (accessed on 27 October 2018).

3. Karekezi, S.; McDade, S.; Boardman, B.; Kimani, J.; Lustig, N. Energy, poverty, and development. In Global Energy Assessment Writing Team, Global Energy Assessment: Toward a Sustainable Future; Cambridge University Press: Cambridge, UK, 2012; pp. 151-190. [CrossRef]

4. Chakravarty, S.; Tavoni, M. Energy poverty alleviation and climate change mitigation: Is there a trade off? Energy Econ. 2013, 40, S67-S73. [CrossRef]

5. Dagoumas, A.; Kitsios, F. Assessing the impact of the economic crisis on energy poverty in Greece. Sustain. Cities Soc. 2014, 13, 267-278. [CrossRef]

6. Atkinson, A.B.; Bourguignon, F. The comparison of multi-dimensioned distributions of economic status. Rev. Econ. Stud. 1982, 49, 183-201. [CrossRef]

7. Pachauri, S.; Spreng, D. Measuring and monitoring energy poverty. Energy Policy 2011, 39, 7497-7504. [CrossRef]

8. International Energy Forum. Energy access and affordability. In Proceedings of the Paper Presented at the 16th International Energy Forum Ministerial, New Delhi, India, 10-12 April 2018; Available online: https:/ /www.ief.org/_resources/files/events/ ief16-ministerial/ief16-ofid-background-paper.pdf (accessed on 27 October 2018).

9. Aftab, S. Pakistan's Energy Crisis: Causes, Consequences and Possible Remedies; The Norwegian Peacebuilding Resource Centre: Oslo, Norway, 2014; Available online: https:/ / www.files.ethz.ch/isn/177484/ade59fba5daf67a11a1c217434abf440.pdf (accessed on 27 October 2018).

10. Javed, M.S.; Raza, R.; Hassan, I.; Saeed, R.; Shaheen, N.; Iqbal, J.; Shaukat, S.F. The energy crisis in Pakistan: A possible solution via biomass-based waste. J. Renew. Sustain. Energy 2016, 8, 43102. [CrossRef]

11. Boardman, B. Fuel Poverty: From Cold Homes to Affordable Warmth; Belhaven Press: London, UK, 1991; Available online: https: / /books.google.fr/books/about/Fuel_Poverty.html?id=HwYtAAAAMAAJ\&redir_esc=y. (accessed on 27 October 2018).

12. Schuessler, R. Energy poverty indicators: Conceptual issues-Part I: The ten-percent-rule and double median/mean indicators. ZEW-Cent. Eur. Econ. Res. Discuss. Pap. 2014. [CrossRef]

13. Mahmood, R.; Shah, A. Deprivation counts: An assessment of energy poverty in Pakistan. Lahore J. Econ. 2017, $22,109-132$. [CrossRef]

14. Qurat-ul-Ann, A.-R.; Mirza, F.M. Multidimensional energy poverty in Pakistan: Empirical evidence from household level micro data. Soc. Indic. Res. 2021, 155, 211-258. [CrossRef]

15. Foster, V.; Tre, J.-P.; Wodon, Q. Energy prices, energy efficiency, and fuel poverty. In Latin America and Caribbean Regional Studies Programme; World Bank: Washington, DC, USA, 2000; Available online: https://citeseerx.ist.psu.edu/viewdoc/download?doi= 10.1.1.557.1335\&rep=rep1\&type=pdf (accessed on 27 October 2018).

16. Wang, K.; Wang, Y.X.; Li, K.; Wei, Y.M. Energy poverty in China: An index based comprehensive evaluation. Renew. Sustain. Energy Rev. 2015, 47, 308-323. [CrossRef]

17. Nussbaumer, P.; Bazilian, M.; Modi, V. Measuring energy poverty: Focusing on what matters. Renew. Sustain. Energy Rev. 2012, 16, 231-243. [CrossRef]

18. Ketting, N.G. Towards a sustainable energy future. Energy Policy 1995, 23, 637-638. [CrossRef]

19. Sovacool, B.K. The political economy of energy poverty: A review of key challenges. Energy Sustain. Dev. 2012, 16, 272-282. [CrossRef] 
20. Day, R.; Walker, G.; Simcock, N. Conceptualising energy use and energy poverty using a capabilities framework. Energy Policy 2016, 93, 255-264. [CrossRef]

21. González-Eguino, M. Energy poverty: An overview. Renew. Sustain. Energy Rev. 2015, 47, 377-385. [CrossRef]

22. International Energy Agency. World Energy Outlook. 2012. Available online: https://webstore.iea.org/world-energy-outlook-20 12-2. (accessed on 27 October 2018).

23. Latief, R.; Kong, Y.; Peng, Y.; Javeed, S.A. Conceptualizing pathways of sustainable development in the union for the mediterranean countries with an empirical intersection of energy consumption and economic growth. Int. J. Environ. Res. Public Health 2020, 17, 5614. [CrossRef] [PubMed]

24. Shahbaz, M. Measuring Economic Cost of Electricity Shortage: Current Challenges and Future Prospects in Pakistan; Munich Personal RePEc Archive (MPRA) Paper 67164; 2015; Available online: https:/ /mpra.ub.uni-muenchen.de/67164/1/MPRA_paper_67164. pdf (accessed on 27 October 2018).

25. Knotek, E.S., II. How useful is Okun's law? Econ. Rev.-Fed. Reserve Bank Kans. City 2007, 92, 73-103.

26. Bollino, C.A.; Botti, F. Energy poverty in Europe: A multidimensional approach. PSL Q. Rev. 2017, 70, 473-507. [CrossRef]

27. Ullah, S.; Mahmood, T. Energy consumption and four growth hypotheses: An evidence from SAARC Nations. Rev. Econ. Dev. Stud. 2020, 6, 833-843. [CrossRef]

28. Yu, S.; Sial, M.S.; Tran, D.K.; Badulescu, A.; Thu, P.A.; Sehleanu, M. Adoption and implementation of sustainable development goals (SDGs) in China-Agenda 2030. Sustainability 2020, 12, 6288. [CrossRef]

29. Okushima, S. Gauging energy poverty: A multidimensional approach. Energy 2017, 137, 1159-1166. [CrossRef]

30. Thiam, D.R. Renewable energy, poverty alleviation and developing nations: Evidence from Senegal. J. Energy S. Afr. 2011, 22, 23-34. Available online: http://www.scielo.org.za/pdf/jesa/v22n3/04.pdf. (accessed on 27 October 2018). [CrossRef]

31. Papageorgiou, C.; Saam, M.; Schulte, P. Substitution between clean and dirty energy inputs: A macroeconomic perspective. Rev. Econ. Stat. 2017, 99, 281-290. [CrossRef]

32. Zaman, R.; Brudermann, T. Energy governance in the context of energy service security: A qualitative assessment of the electricity system in Bangladesh. Appl. Energy 2018, 223, 443-456. [CrossRef]

33. Bazilian, M.; Nakhooda, S.; Van de Graaf, T. Energy governance and poverty. Energy Res. Soc. Sci. 2014, 1, 217-225. [CrossRef]

34. Khalid, I.; Mukhtar, A. Energy crisis: An issue of good governance, a way forward. J. Political Stud. 2016, 23, 101-116. Available online: http:/ / pu.edu.pk/images/journal/pols/pdf-files/7-IRAM-ASIA_v23_1_16.pdf (accessed on 22 November 2018).

35. Amjad, R.; Burki, S.J. (Eds.) Pakistan: Moving the Economy Forward; Cambridge University Press: Delhi, India, 2015.

36. Van de Graaf, T.; Colgan, J. Global energy governance: A review and research agenda. Palgrave Commun. 2016, 2, 1-12. [CrossRef]

37. Bradley, R. Comment-Defining health insurance affordability: Unobserved heterogeneity matters. J. Health Econ. 2009, 28, 255-264. [CrossRef]

38. Whitehead, C.M.E. From need to affordability: An analysis of UK housing objectives. Urban Stud. 1991, 28, 871-887. [CrossRef]

39. Department of Energy \& Climate Change. In Annual Report on Fuel Poverty Statistics 2011; National Statistics Publication: London, UK, 2011. Available online: https://assets.publishing.service.gov.uk/government/uploads/system/uploads/attachment_data/ file/48138/2181-annual-report-fuel-poverty-stats-2011.pdf (accessed on 22 November 2018).

40. Khan, R.E.A.; Ullah, S. Measuring the governance in Pakistan: An introduction to KU Index. Acta Econ. 2014, 12, 23-41. Available online: http:/ / store.ectap.ro/articole/1009.pdf (accessed on 22 November 2018). [CrossRef]

41. Greco, S.; Ishizaka, A.; Tasiou, M.; Torrisi, G. On the methodological framework of composite indices: A review of the issues of weighting, aggregation, and robustness. Soc. Indic. Res. 2019, 141, 61-94. [CrossRef]

42. Gisselquist, R.M. Good Governance as a Concept, and Why This Matters for Development Policy; WIDER Working Paper; United Nations-World Institute for Development Economics Research (UNU/WIDER): Helsinki, Finland, 2012.

43. Brown, T.A.; Moore, M.T. Confirmatory factor analysis. In Handbook of Structural Equation Modeling; Hoyle, R.H., Ed.; The Guilford Press: New York, NY, USA, 2012; pp. 361-379.

44. Snook, S.C.; Gorsuch, R.L. Component analysis versus common factor analysis: A Monte Carlo study. Psychol. Bull. 1989, 106, 148-154. [CrossRef]

45. Mishra, M. Confirmatory factor analysis (CFA) as an analytical technique to assess measurement error in survey research: A review. Paradigm 2016, 20, 97-112. [CrossRef]

46. Sarmento, R.; Costa, V. Comparative Approaches to Using R and Python for Statistical Data Analysis; IGI Global: Hershey, PA, USA, 2017. [CrossRef]

47. Culver, L.C. Energy poverty: What you measure matters. In Paper presented at the Proceedings of the Reducing Energy Poverty with Natural Gas: Changing Political; Business and Technology Paradigms Symposium: Stanford, CA, USA, 2017; Available online: https://ngi.stanford.edu/sites/default/files/NGI_Metrics_LitReview\%282-17\%29.pdf (accessed on 22 November 2018).

48. Pachauri, S.; Brew-Hammond, A.; Barnes, D.F.; Bouille, D.H.; Gitonga, S.; Modi, V.; Prasad, G.; Rath, A.; Zerriffi, H.; Dafrallah, T.; et al. Energy access for development. In Global Energy Assessment Writing Team, Global Energy Assessment: Toward a Sustainable Future; Cambridge University Press: Cambridge, UK, 2012; pp. 1401-1458. [CrossRef]

49. Solow, R.M. A contribution to the theory of economic growth. Q. J. Econ. 1956, 70, 65-94. [CrossRef]

50. Mankiw, N.G.; Romer, D.; Weil, D.N. A contribution to the empirics of economic growth. Q. J. Econ. 1992, 107, 407-437. [CrossRef]

51. Doğanalp, N.; Ozsolak, B.; Aslan, A. The effects of energy poverty on economic growth: A panel data analysis for BRICS countries. Environ. Sci. Pollut. Res. 2021, 1-12. [CrossRef] 
52. Amin, A.; Liu, Y.; Yu, J.; Chandio, A.A.; Rasool, S.F.; Luo, J.; Zaman, S. How does energy poverty affect economic development? A panel data analysis of South Asian countries. Environ. Sci. Pollut. Res. 2020, 27, 31623-31635. [CrossRef]

53. Kubik, R. Looking for the right human capital proxy. Rev. Econ. Perspect. 2010, 10, 61-70. [CrossRef]

54. Khan, M.Z.; Khan, F.N. Estimating the demand for rail freight transport in Pakistan: A time series analysis. J. Rail Transp. Plan. Manag. 2020, 14, 100176. [CrossRef]

55. Barro, R.J. Economic Growth in a Cross Section of Countries. Source Q. J. Econ. 1991, 106, 407-443. [CrossRef]

56. Laverde-Rojas, H.; Correa, J.C.; Jaffe, K.; Caicedo, M.I. Are average years of education losing predictive power for economic growth? An alternative measure through structural equations modeling. PLoS ONE 2019, 14, e0213651. [CrossRef] [PubMed]

57. World Bank. World Development Indicators (WDI). Data Cat. 2019. Available online: https://datacatalog.worldbank.org/ dataset/world-development-indicators (accessed on 20 June 2019).

58. Dickey, D.A.; Fuller, W.A. Distribution of the estimators for autoregressive time series with a unit root. J. Am. Stat. Assoc. 1979, 74, 427-431. [CrossRef]

59. Phillips, P.C.B.; Perron, P. Testing for a unit root in time series regression. Biometrika 1988, 75, 335-346. [CrossRef]

60. Stock, J.H.; Watson, M.W. A simple estimator of cointegrating vectors in higher order integrated systems. Econometrica 1993, 61, 783-820. [CrossRef]

61. Johansen, S.; Juselius, K. Maximum likelihood estimation and inference on cointegration-With applications to the demand for money. Oxf. Bull. Econ. Stat. 1990, 52, 169-210. [CrossRef]

62. Ahmad, N.; Du, L. Effects of energy production and $\mathrm{CO}_{2}$ emissions on economic growth in Iran: ARDL approach. Energy 2017, 123, 521-537. [CrossRef]

63. Masih, A.M.M.; Masih, R. Energy consumption, real income and temporal causality: Results from a multi-country study based on cointegration and error-correction modelling techniques. Energy Econ. 1996, 18, 165-183. [CrossRef]

64. Judson, R.A.; Schmalensee, R.; Stoker, T.M. Economic development and the structure of the demand for commercial energy. Energy J. 1999, 20, 29-57. [CrossRef]

65. Toman, M.T.; Jemelkova, B. Energy and economic development: An assessment of the state of knowledge. Energy J. 2003, 24, 93-112. [CrossRef]

66. Ang, J.B. Economic development, pollutant emissions and energy consumption in Malaysia. J. Policy Modeling 2008, 30, 271-278. [CrossRef]

67. Lin, B.; Raza, M.Y. Coal and economic development in Pakistan: A necessity of energy source. Energy 2020, 207, 118244. [CrossRef] 